\title{
THE IMPLEMENTATION OF QUESTIONING STRATEGY IN TEACHING SPEAKING FOR THE TENTH GRADE IN MA AL-ABROR BLUMBUNGAN PAMEKASAN
}

\author{
Ina Daril Hanna; Arisandi setiyawan \\ Ina.daryl@yahoo.com; ase.sun86@gmail.com \\ Universitas Islam Madura
}

\begin{abstract}
Teaching speaking is an important part of language learning so that the English teacher should use some strategies to improve the students' speaking skill. At the tenth grade of MA AL-ABROR Blumbungan Pamekasan, the English teacher used questioning strategy to encourage the students to be better in speaking. That is why the researchers want to describe the phenomena further in the research entitled the implementation of questioning strategy in teaching speaking for the tenth grade in MA AL-ABROR Blumbungan Pamekasan. The aim of this research was to find out how was the implementation of questioning strategy for the tenth grade in MA AL-ABROR Blumbungan Pamekasan, what types of the question were used by the teacher in the implementation of questioning strategy for the tenth grade in MA AL-ABROR Blumbungan Pamekasan,and how did the responses of thestudents in the implementation of questioning strategy for the tenth grade in MA AL-ABROR Blumbungan Pamekasan. The instruments used by the researchers answer observation, interview and documentation in collecting the data.The results were 1 . the teacher used questioning strategy by using some steps in teaching speaking, the first step is deciding the topic related with the students' environment, then He give some vocabullaries related to the topic. Then teacher choose some students who have low ability and medium or high ability in speaking to treat them in giving them both the convergent questions and divergent questions. The last The teacher use increasing wait-time when the students need time to think about the questions, 2.The teacher used convergent and divergent questions, it was done to make the students have better understanding in speaking and the students can be easy in answering the question given by the teacher. 3 . The student's responses in implementing of questioning strategy are various, they were comfort, nervous, afraid but They could enjoy it because the topic relate with their environment.
\end{abstract}

Keywords: Questioning Strategy, Teaching Speaking

\section{INTRODUCTION}

Speaking is one of skill that can assist the development of the other English skills like reading, listening, and writing. Speaking is very important skill for the students to master because by speaking the students can explore their English and they also can practice the target language which are learned orally. Speaking or oral communication skill seems to be the most important and most foreign language learners are primarily interested in learning to speak (Nunan, 1999: 8)

Teaching speaking is an important part of language learning. The ability to communicate and interact in the target language clearly and efficiently will contribute to the success of the students.
Furthermore, English becomes an international language that will be needed by the students in the future. Therefore, it is also important for the English teacher to pay great attention in teaching speaking.

The researchers as an English lecturer have got information from the teacher that the students have low motivation in speaking English, He said that the students could not speak english bravely and they got problem in developing the topic when they spoke in English. So that He want to encourage them to be active in speaking so that the students can improve their speaking ability well. He added that they have just a little vocabulary to do speaking. Most of them were getting silent when He gave some questions in English. It becomes a big problem in English 
teaching if the English teacher does not find a good strategy to solve it. Then $\mathrm{He}$ used one of the learning strategy,that is questioning strategy in Contextual Teaching and Learning (CTL). Muslich (2007) defines the foundation of philosophy in Contextual Teaching Learning (CTL) is constructivism, which emphasizes that learning is not only memorizing but also reconstructing or constructing new knowledge and new competence through facts or proportion which they experience in their life (p. 41)

According to Nurhadi (2002: 45), questioning is the main strategy of Contextual Learning, because knowledge usually start from questioning. In learning process, questioning is considered as Teachers' activity to support, guide, and evaluate students to dig information, analyzing and explore ideas.

As Döş*, Bülent et all (2006) stated that There are two main classifications of questioning based on student response. Generally, questions with a single correct answer, short, and intended to recall acquired information are called convergent questions. These questions are also referred to as closed-ended questions as students are not expected to contribute to an original idea. For example, after teaching about animals that change color, the teacher then ask "Which animals are chatoyant?"; this question is a convergent question. On the other hand, questions which students answer by analysis, synthesis, or evaluation using their related knowledge of a question, a problem or a situation are referred to as divergent questions. Divergent questions are openended questions and may have multiple answers. For example, "What kinds of problems chatoyant animals might face if they lost this characteristic?" is a divergent question. For such a question, students are supposed to know the chatoyant animals and their characteristics, know about their wild-life conditions and contribute original opinions.

There are some steps that teacher can use in using questioning strategy as $\mathrm{Ma}$ stated that, before asking questions in class, the preparation is required are: Deciding on the purpose for questioning, Selecting content for questioning, Phrasing the questions, and Anticipating Problems (2008:94-95).

Ma (2008: 96-97) also proposed some Skills of controlling for questioning like:

1. Nominating after the Question

The way of questioning is asking questions first, giving students time to think and then ask nominating student to answer. If you nominate students before you asking question, there will be just the nominated student thinking this question, while the other students considered not involved.

\section{Nominating Non-volunteers}

Students become distracted easily or do something by their own. When teachers ask questions, they can ask silent students deliberately, it can let students pay attention to your class. Nonvolunteers will think they are taken seriously when teachers ask a question to them. And they will feel very well and they will participate in classroom instructions after that, and they will feel spunky.

\section{Probing}

Probing is another important questioning skill. (Note 16) Probes are based on student responses. The initial response of students may be superficial. The Teacher needs to use a questioning strategy called probing to make students explore initial comments. Probes are useful in getting students more involved in critical analysis of their own and other students' ideas. If the student does not provide a complete answer, he or she may know a partial answer.

4. Increasing Wait-time 
An important dimension of teacher's questioning skills is halting time, or wait time, that is, the length of time the teacher waits after asking the question before calling on a student to answer it, rephrasing the question., directing the question to another student, or giving the answer. (Note 17) That is called wait time, and it is amazing how few teachers

use this important questioning skill. Directing Attention to All In actual classroom interaction, the teacher will automatically cover high achievers, focus on the students in the first few rows and choose the selected few students to answer questions. And the teacher may not sometimes realize this when asking students questions. All these will result in the improper distribution of the questions to the students.

In this research, the researchers wants to describe the phenomena further on how teaching speaking for the tenth grade in MA Al-Abror Blumbungan Pamekasan on questioning strategy used in teaching speaking.

The researchers formulates the research entitle," The Implementation of Questioning Strategy in Teaching Speaking For The tenth grade in MA AlAbror Blumbungan Pamekasan. This research focused on what kinds of questionings that the English teacher implemented and what responses that the students gave.

\section{METHOD}

In this research the writer used qualitative approach. The kind of research used by the writer was descriptive research. It is used to give description more detail about this research. According to Bogdan and Taylor, "Qualitative research is a research procedure, which produces descriptive data in the form of written words, or oral and the behavior of the people observed" (Moleong, 2002:3).
In qualitative research, the data are analyzed in the form of phenomenon on description not numeral (Arikunto, 2006:12). Thus, this research does not measurement or statistical data. The data is described in the form of words and sentences, or paragraph relating with to the text, which the writer finds in the process of study.

Therefore, the researchers used the descriptive qualitative design to study developing phenomena in the first tenth grade of MA Al-Abror Blumbungan, so that the writer got valid data to conclude problems, because the researchers met the subject sources directly at MA Al- Abror Blumbungan. The subject could be observed, identified and the result would be scientifically analyzed.

The subject of this research was the tenthgrade students in MA AL-Abror Blumbungan Pamekasan, The researchers used XB Class consisting of 24 students that focus on the teaching learning activities. This strategy gave some simple questions for students. The questions could be given by teacher to students so that they could improve their English skill especially in Speaking. It is observed to find about the implementation of the questioning strategy, the type of questioning strategy teacher used in teaching speaking, the students' response in implementing questioning strategy.

The researchers used some instruments like observation, interview and documentation In collecting the data. The researchers observed the English teacher and students to acquire the data concerning with the process of teaching speaking in the implementation questioning strategy applied by the teacher in classroom. The researchers observed the students when they were given some simple questions then the writer note kinds of question and the result all of the students activities in the class. 
The researchers interview the teacher and the students in the implementation of questioning strategy in teaching speaking, types of question used by the teacher, and the responses of the students while teaching learning process using questioning strategy in teaching speaking for the tenth gradeinn MA AL-ABROR Blumbungan Pamekasan.

The other technique used by the writer to collect data was documentation. Data was gotten from photo, transcript, books attendance list of students, and files which related with research focus above.

\section{DISCUSSION}

\section{The Implementation of Questioning Strategy}

The implementation of questioning give significance role in teaching and learning process in the tenth grade in MA AL-Abror Blumbugan Pamekasan. Based on the observation conducted by theresearchers during teaching and learning process, the teacher used qustioning in teaching speaking. It was done to make the students got progress in speaking skills. It was suitable with the result of interview with the teacher stated that :

"Questioning is so important to be implemented in speaking class, because it will be demanded the students to speak in English by delevering the answer. When they catch the questions, they willthink about how to answer it.So that the mastering vocabularies is also important to support their speaking"

The teacher also added some statement that:

"In using questioning strategy by delivering convergent and divergent questions, it makes the students catch the question easily and they are also encouraged to be more active like their friend get good progress in speaking."
The teacher started by introducing the topic of the material at that meeting. It is about the descriptive text, the teacher take the topic about Tourist Destination. Teacher decided to take the topic about some tourist destinations in Madura in order that the students understood the questions that teacher give easily.

This is the transcript of the observation when the teacher implement the questioning strategy in the class:

Teacher: 'How are you?'

Student : 'I am fine sir, thank and you?'

Teacher: 'I am fine too, thank you'

Teacher: 'By the way, which one do you like between camplong beach or jumiang beach?'

Student : 'camplong beach sir

Teacher : 'is it beautiful ?'

Student : 'yes it is beautiful sir'

Teacher: 'do you go wth firend or your family?'

Student : 'family sir.

Teacher : 'are you happy at that time?'

Student : 'apa at that time sir ("pada waktu itu" teacher), yes I was

Teacher : "how did you come there with motor ciycle or car?

Student : 'with motor cycle sir'

Here, the teacher asked the students by using the topic about the tourist destination in madura, it was proved that the students could relate his real experience with the questions.So that he could answer bravely.

As a result of in interview with the teacher, The teacher stated that:

"The students should be given some interesting topic about their environment, but it must related to the material.The purpose is the students can participate in speaking activities. So they can answer the question easily"

The second step, the teacher gave some vocabularies that would exist during the speaking activity so that the students would get easy in answer all of the questions. 
As the result of the interview, the teacher stated that:

"To support the students to be more active in speaking, I give them some viocabullaries that will be used during the speaking activity in order that they will not confuse when they get the questions. It will be helpfull for them"

It is strengthened by the students statement as following:

"The question that teacher gave were related to our environment so that it make us easy to understand and answer the questions. It is also supported by some vocabullaries teacher give to us before speaking activity was started.

Then the third step teacher choosed the students who were considered to have the low ability and the students who had medium or high ability in speaking.Teacher used convergent questions For the students with low ability in speaking, and teacher used divergent question for the students wit medium or high ability in speaking.

As the result of interview, the teacher said that:

"I choose students who have low ability and medium or high ability in speaking, It was done to make the teacher easy in delivering the questions because teacher treat the students in different way.I use the convergent questions to the students with low ability and divergent questions to the students with medium or high ability in speaking"

The last step was the teacher using increasing wait-time for the student who was confused to answer the question. It was done to give the students think more about what they want to deliver. So that they were enjoy when they were speaking.

It is strengthened by the teacher's statement as following:

"I do not forget to give a little time to the students (wait-time) to think about their answer. Furthemore it needed by students who were lack of some vocabullaries. It aimed to encourage their effort in speaking".

Based on the result of the observation and the interview above, it can conclude that the implementation of the questioning strategy in the tenth grade of MA ALAbror Blumbungan was started by deciding the topic related with the students' environment, then they give some vocabullaries related to the topic.After that teacher choose some students who have low ability and medium or high ability in speaking to treat them in giving them both the convergent questions or divergent questions. The last Teacher use incresing wait-time for students to to make the students were ready to speak.

\section{The Type of Questions}

The data was taken from the researcher's note about some type of question the teacher used to the students depended on students' speaking ability. The English teacher used some type of questions that are convergent questions and divergent questions. The teacher used convergent questions to the students that have low ability in speaking. And the divergent questions were used by the teacher to asked the students who have middle and good ability in speaking.

This is the transcript of the observation when the teacher used convergent questions.

Teacher: 'By the way, which one do you like between camplong beach or jumiang beach?'

Student : 'camplong beach sir'

Teacher : 'is it beautiful ?'

Student : 'yes it is beautiful sir'

Teacher : 'do you go with firend or your family?'

Student : 'family sir.

Teacher : 'are you happy at that time?'

Student : 'apa at that time sir ("pada waktu itu" teacher), yes I was 
Teacher : 'how did you come there with motor ciycle or car?

Student : 'with motor cycle sir'

The teacher used convergent questions because it concludes with closed-ended questions that make the students did not think deeply when they catched they questions. It could also build their confident automatically.

As stated by the teacher:

"I used so simple question called convergent questions to encourage students that have low ability in speaking becausethis types of question will make the students easy in giving response to the question".

Based on the observation conducted by the writer during teaching and learning process shows that the English teacher used convergent questions that are also referred to as closed ended question in order to make the students easy and get used to speak English in the class.

The convergent questions made the student feel comfort and the students interested in learning and joining the class. the proof showed that the students can be active and responsive in answering and responding the question given by the teacher.

The teacher also stated that:

"I am not only use convergent questions to my students but also divergent question, it is used for the students with medium up to high level ability in speaking. There are three kinds of students based on the level ability in speaking. So I as the teacher find the solution to treat them differently in teaching speaking. In order the students with low level can be motivated to be more active in speaking".

This is the transcript of the observation when the teacher used disvergent questions:

Teacher : 'How are you?'

Student : 'I am fine sir, thank and you?'
Teacher : 'I am fine too, thank you'

Teacher : 'By the way, what is your favourite place to visit in pamekasan?'

Student : 'I think My favourite place is Jumiang beach"

Teacher : 'Why do you like it?'

Student : 'because it is one of beautifull place in pamekasan'

Teacher : 'When did the last time you go?

Student : 'I went there 2 weeks ago sir'

Teacher: 'with whom did you go?'

Student : "with my friends"

Teacher : 'were you happy at that time?'

Student : 'yes I was, sir"

Teacher: 'how did you come there?

Student : 'I came there by motor cycle'

The divergent question is more suitable for the students that master vocabullary or the students with high ability in speaking. It encouraged them to speak more about the answer.

It is suitable with the result of observation conducted by the researchersthat the teacheronly used two type of questions, they are convergent question and divergent question depend on the level of students'ability in speaking. The teacher treated the studentst differently in teaching speaking because he relized that the students have different level ability in speaking so he should also treat them in different way. He used covergent question to the students with low level ability in speaking in order that the they were encouraged to speak although in a simple answer. The students should not think hard to answer the convergent questions because it is a simple question that does not need deep understanding So the students be easier in answer.

In other side, the teacher used divergent questions to the students who have high-level ability in speaking because it can help they have already had much vocabularies than the other so it can 
be used to increase their speaking ability. It is because Divergent questions need multiple answer and deep understanding to the question so it is very suitble for the students in high level ability.

Based on the interview and observation conducted by the researchers during teaching and learning process at the tenthgrade of MA AL-ABROR Blumbungan Pamekasan it showed that the Englishteacheris used convergent and divergent question in engaged the students to speak actively.It was done to make the students have better understanding in speaking and the students can be easy in answering the question given by the teacher.

\section{The Responses of The Students}

The students' response were various, some of the students felt comfort and some of the students felt nervous when the teacher asked the students.

As a result of interview with the student stated as following: "I feel comfortable in join the speaking class, although I get nervous at the first but the teacher make me confident by giving me some questions that $i$ can answer and he give me a chance to think about the answer and I like the topic"

It is strength with the other students stated that:

"Actually i do not know about speaking, I never enjoy this class before. But now I am motivated to know more about English especially speaking. I want to be master like the others"

It is supported by the teacher's statement:

"When the students feel afraid and nervous I give them wait time to think more about the questions and they can ask about some word that they do not understand"

Based on the result of interview and observation conducted by the researchers it can be conclude that the student's response are various, namely; comfort, nervous, afraid but although they feel so, the students are motivated study and speak English actively.

\section{CONCLUSION}

Based on the interview and observation conducted by the researchers during teaching and learning process at the tenthgrade of students in MA ALAbror Blumbungan Pamekasanit can conclude that:

1. The teacher used questionning stratgey by using some steps in teaching speaking, the first step is deciding the topic related with the students' environment, then they give some vocabullaries related to the topic. Then teacher choose some students who have low ability and medium or high ability in speaking to treat them in giving them both the convergent questions or divergent questions. The last The teacher use increasing wait-time when the students need time to think about the questions

2. The teacher used convergent and divergent questions, it was done to make the students have better understanding in speaking and the students can be easy in answering the question given by the teacher.

3. The student's responses in implementing of questioning strategy are various, they were comfort, nervous, afraid but they could enjoy every steps in the speaking activities. They were also enthusiastic to the questions so that they thought the answers easily because the topic was about their environment.

Regarding the conclusion stated previously, the researchers would like to propose several suggestions for:

1. English Teacher of The Tenth Grade in MA AL-Abror Blumbungan Pamekasan 
The teacher should implement questioning strategy in other topic of the material that relate to the students environment and teacher had better add more vocabularies to prepare the students before speaking. The teacher should also try the other strategies in order that the students do not feel boring in the class. So that teacher get much experience in facing the students' problem in teaching speaking

2. The students of The Tenth Grade in MA AL-ABROR Blumbungan Pamekasan

The students should try to practice the speaking skill in order that they can get good speaking then the students should try to memorize much vocabularies given by the teacher so that they can be ready when they want to speak English

3. The Future Researchers

The future researchersshouldhold some researchs with the same strategy in the other grade of school so that it can be a good references for all of English teachers to be implemented in their English teaching.

\section{REFERENCES}

\section{Arikunto, S. 2006. Prosedur Penelitian} Suatu Pendekatan Praktik, Jakarta: Rineka Cipta.

Döş*, Bülent et all.2016.An Analysis of Teachers'Questioning Strategies.
Academic

Journals, vol.11(22).Turkey:Gaziante pUniversity

(http://www.academicjournals.org/j ournal/ERR/article-full-textpdf/A09F37161683 accessed on wednesday-08-nov-2017-10.30 am)

Ma, Xiaoyan.2008.The Skills of The teacher's Questioning in English Classes.International Education Studies, vol.1 no.4. Chongqing: Yangtze Normal University (https://files.eric.ed.gov/fulltext/EJ1 065462.pdf accessed on thursday 09-nov-2017-10.00 am)

\section{Moleong, Lexi J. 2002. Metodelogi}

Penelitian Kualitatif.

Bandung:Remaja Rosdakarya .

Muslich, M.2007.KTSP Pembelajaran

Berbasis Kompetensi danKontekstual:Panduan Bagi Guru, Kepala Sekolah, dan Pengurus Sekolah.Jakarta: Bumi Aksara.

Nunan, D. 1999. Second Language Teaaching and Learning. Boston: Heinle\&Heinle

Nurhadi. 2004. Kirikulum 2014:

Pertanyaan dan Jawaban. Jakarta:

Grasindo 